\title{
Do edaphic aspects alter vegetation structures in the Brazilian restinga?
}

\author{
Francisco Soares Santos-Filho ${ }^{1,4}$, Eduardo Bezerra Almeida $\mathrm{Jr}^{2}$ and Carmen Sílvia Zickel ${ }^{3}$
}

Received: 23 May, 2011. Accepted: 24 July, 2013

\begin{abstract}
The vegetation of the Brazilian restinga (coastal woodland) presents a variety of species and different characteristics, encompassing fields, fruit groves and forests on quartzarenic neosols. We hypothesised that the structure of the restinga landscape along the coast of the state of Piauí is influenced by edaphic factors and presents a pattern similar to that of other northeastern restingas. We evaluated three restingas in Piauí, using the quarter method to determine their structure. Composite soil samples were collected to determine their chemical and physical properties. Edaphic variables were correlated with plant species by canonical correspondence analysis (CCA). Phytosociological data for all three areas indicated regenerating vegetation comprising several small individuals, $82.5 \%$ of which showed a diameter at ground level $\leq 13 \mathrm{~cm}$. We also observed considerable tillering. In two of the areas, there was a predominance of Fabaceae species, such as Caesalpinia pyramidalis and Copaifera martii. Although the structural characteristics of the restingas studied were similar to those of other northeastern restingas, the former showed lower Shannon diversity indices (2.18-2.44). The CCA indicated that species distribution was influenced by edaphic factors such as $\mathrm{pH}$, aluminium content and amount of organic matter. The restingas studied were similar to others along the Brazilian coast.
\end{abstract}

Key words: canonical correspondence analysis, coastal vegetation, edaphic interactions

\section{Introduction}

The Brazilian restinga (coastal woodland) occupies areas along the coastline, with a variety of characteristics that vary depending on edaphic factors, especially those related to water and nutrient availability due to the influence of the sea (Scarano 2000), as well as on topographical and climatic factors. Although the restingas present an wide variety of species, many originated in the Atlantic Forest. Those species could have adapted in order to colonise the geologically young plains (Matallana et. al. 2005). According to Scarano (2002), the restinga does not present endemism, because of its relatively recent establishment.

Although the coast of Brazil, with all its recesses, is more than $9000 \mathrm{~km}$ in length, there have been few studies of its vegetation, especially in the northeast, which has a longer coastline than does any other region of the country (Araújo 1984; 2000). Most studies of the vegetation of the northeastern coast have focused on the state of Pernambuco (Zickel et al. 2007; Sacramento et al. 2007; Silva et al. 2008; Almeida et al. 2009). Despite such studies, little is known about the environment, relationships within plant communities, and ecological processes along the northeastern coast. Phytosociological studies, which are fundamental to understanding the landscape and structural organisation of plant assemblies, as well as to elucidating recruitment processes, regeneration and occupation of areas, are still incipient for this region (Zickel et al. 2004).

In the northeastern Brazilian state of Piauí, the coastline, which forms the northern border of the state, is relatively short $(66 \mathrm{~km})$ and lies completely within the Parnaíba Delta Protected Area. The state is considered an ecotonal zone because of the influences it receives from central Brazil, sub-humid areas of the Amazon and semi-arid areas of other northeastern states (Farias \& Castro 2004). This unique situation, along with the position of the restingas, which are located near the equator, can have a strong influence on the distribution of species in the region (Gentry 1988).

We hypothesised that the structure of the restinga landscape along the coast of the state of Piaui is influenced by edaphic factors and presents a pattern similar to that of other northeastern restingas. We opted to study the coast of Piauí because it is part of a natural, protected area and because of the lack of studies of the vegetation along the northern coast of Brazil. We aimed to test the influence of edaphic factors related to the structure of the woody vegetation. We attempted to answer the following questions regarding the restingas of Piauí: "Is the occurrence of woody plant species related to the chemical and physical conditions of the soil?"; "Is there similarity among areas in terms of the vegetation structure?"; and "Do the structural patterns follow those reported for other restingas along the northeastern coast of Brazil?"

\footnotetext{
${ }^{1}$ Universidade Estadual do Piauí, Centro de Ciências da Natureza, Teresina, PI, Brazil

${ }^{2}$ Universidade Federal do Maranhão, Centro de Ciências Biológicas e da Saúde, Departamento de Biologia, São Luís, MA, Brazil

${ }^{3}$ Universidade Federal Rural de Pernambuco, Recife, PE, Brazil

${ }^{4}$ Author for correspondence: fsoaresfilho@gmail.com
} 


\section{Material and methods}

\section{Characterisation of the study sites}

The Piauí coast is composed of small coves and has four estuarine zones, created by the Parnaíba, Portinho, Camurupim and Ubatuba/Timonha Rivers (Baptista 1981). The coastal zone is located on two geologic formations: deposits of quartzose sand from the Quaternary, which are situated west and extend to the border of the state of Maranhão; and barriers from the Tertiary, which are located to the east, up to the border with the state of Ceará (Sousa \& Rodrigues-Neta 1996). Along the Piauí coast, mangroves are present in the estuaries and there are tabuleiro forests (coastal lowland forests on Tertiary deposits) further inland, in addition to the restingas occupying the backshore region on quartzarenic neosols (Fernandes et al. 1996). In the region with the most restinga formations, some characteristic differences can be observed. Extensive areas are occupied by fields or bush formations (fruit groves), and forest formations occur in other areas.

We selected three restinga landscapes in which there had been little disturbance related to human activity (Fig. 1), located in the following municipalities within Piauí: Ilha Grande (02 50'84"S; 41 $47^{\circ} 39^{\prime}$ 'W, 6.7 km inland); Parnaíba (02 55'48"S; 41 40'67"W, $5.9 \mathrm{~km}$ inland) and Luiz Correia (02 $55^{\prime} 89^{\prime \prime} \mathrm{S} ; 41^{\circ} 30^{\prime} 49^{\prime \prime} \mathrm{W}, 2.3 \mathrm{~km}$ inland). These areas are situated over recent geologic compartments (quartzose sand deposits - BRAZIL 2006) and represent all of the plant formations located on deposits from the Quaternary.
According to the Köppen climate classification system, the climate of the region is type Aw, which is defined as mega-thermal, with a rainy summer and a dry winter (Peel et al. 2007). The average annual temperature of $27.5^{\circ} \mathrm{C}$, and the average annual precipitation is $1223 \mathrm{~mm}$, April being the rainiest month (average precipitation, $297.3 \mathrm{~mm}$ ) and September being the driest (average precipitation, $2.8 \mathrm{~mm}$ ).

\section{Vegetation sampling}

In all three sampling areas, we used the point-centred quarter method to collect phytosociological data (Cottam \& Curtis 1956). In each area, five parallel transects were established, $10 \mathrm{~m}$ apart. On each transect, 10 points were marked, also $10 \mathrm{~m}$ apart, for a total of 50 points. Only plants with a diameter at ground level (DGL) $\geq 3 \mathrm{~cm}$ were included in the analysis.

\section{Collection and identification of the botanical material}

The data collection and identification of the botanical material occurred between October 2006 and March 2008. The botanical material was collected from the studied areas and identified according to standard methodology in vegetal taxonomy by using bibliographical resources (identification keys, original descriptions and a specialised bibliography). In cases of uncertainty, samples were sent for analysis by specialists. The specimens were added to the collection of the Dárdano de Andrade Lima Herbarium of the Pernambuco State Institute of Agronomy (code, IPA).

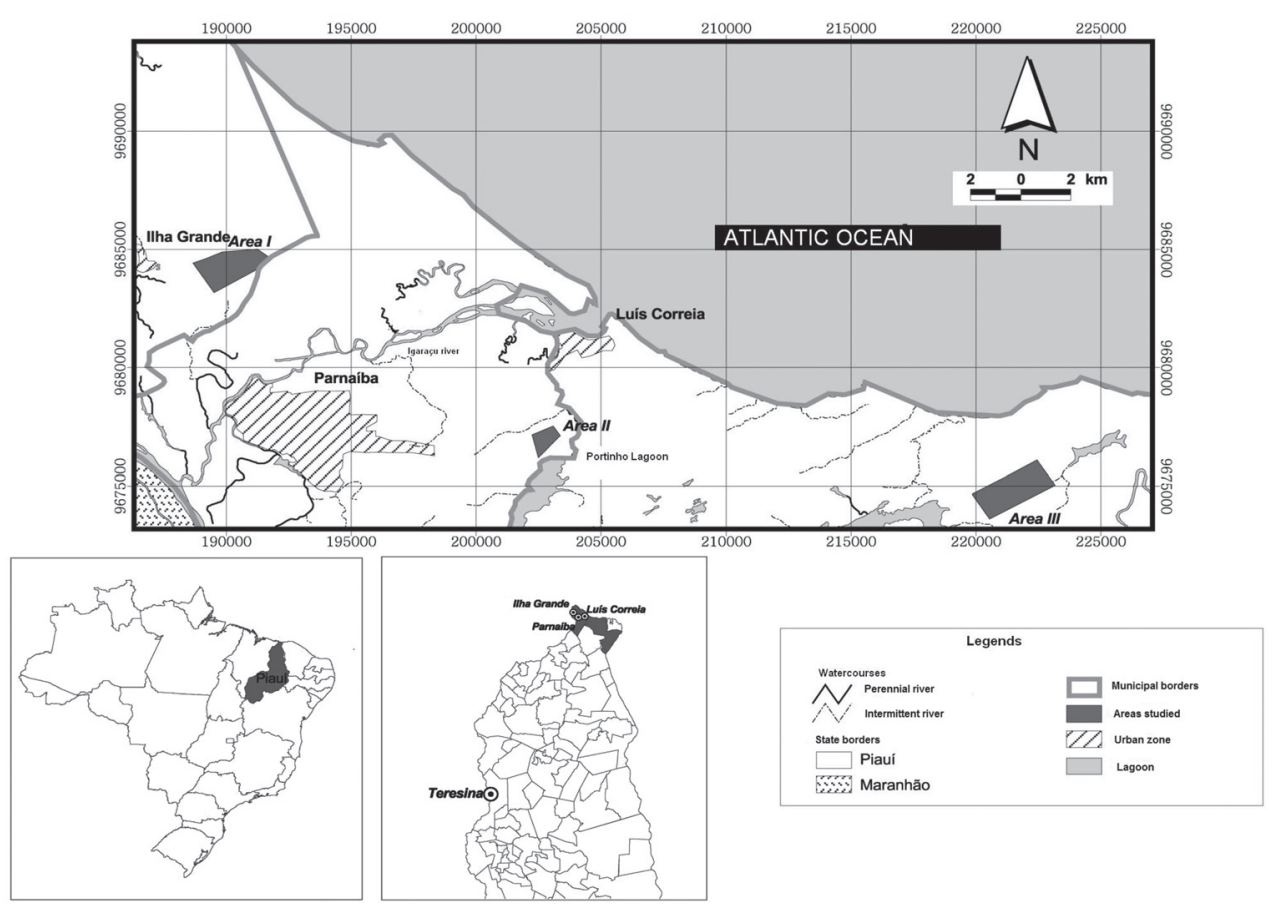

Figure 1. Map of the three sampled areas in the phytosociological studies of the restinga vegetation in the Parnaíba Delta Protected Area, state of Piauí, Brazil. 
The floristic list was organized according to the classification system established in the Angiosperm Phylogeny Group II guidelines (APG II 2003).

\section{Collection and analysis of soil samples}

A total of 25 soil samples were collected from each area, at depths of $0-20 \mathrm{~cm}$. In each transect, five samples were collected at the beginning of the crosspiece, as defined by a sketch, according to the phytosociological method. The samples were homogenised based on the recommendations of Rocha et al. (2004). Each transect was represented by a composite sample, with a total of five samples for each area. We then determined the physical characteristics, including grain size, and conducted chemical analyses to determine $\mathrm{pH}, \mathrm{P}, \mathrm{Na}, \mathrm{K}, \mathrm{Ca}, \mathrm{Ca}+\mathrm{Mg}, \mathrm{Al}, \mathrm{H}+\mathrm{Al}, \mathrm{C}$, cation exchange capacity and the amount of organic matter. The granulometric and chemical analyses followed the methodology described by the Brazilian Agency for Agricultural Research (Embrapa 1997).

\section{Treatment and statistical analysis of the data}

Phytosociological parameters-basal area; relative density; relative dominance; relative frequency; importance value (IV); covering value; and Shannon diversity index $\left(\mathrm{H}^{\prime}\right)$ and Pielou's evenness index $\left(\mathrm{J}^{\prime}\right)$ for families and species-were calculated with the FITOPAC package (Shepherd 1995).

Statistical tests were carried out to determine means and standard deviations related to the physical and chemical analyses of the soil and were obtained through the non-parametric Kolmogorov-Smirnov test (Zar, 1996). Statistical calculations were made with the Statistical Package for the Social Sciences, version 10.0 for Windows (SPSS Inc., Chicago, IL, USA). The values of H' for the areas were tested with the Hutcheson t-test (Hutcheson, 1970). Using the software PC-ORD for Windows, Version 4.14 (McCune \& Mefford 1999), we performed a canonical correspondence analysis (CCA) to test the correlations between species and edaphic factors. Among other functions, the CCA allows direct gradient order analysis, in order to describe the arrangement of species in relation to the edaphic variables. Two matrices were built for the CCA analyses. In the first matrix, data related to the absolute frequency of species represented by two or more individuals were included; rare species (represented by a single individual) were excluded (Martins 1989). The second matrix included all chemical variables- $\mathrm{pH}, \mathrm{P}, \mathrm{Na}, \mathrm{K}, \mathrm{Ca}$, $\mathrm{Ca}+\mathrm{Mg}, \mathrm{Al}, \mathrm{H}+\mathrm{Al}, \mathrm{C}$, cation exchange capacity and amount of organic matter-and physical variables-proportions of sand, clay, and silt. After a preliminary CCA, seven variables that were weakly correlated or highly redundant with other variables were eliminated. The final CCA was processed with the variables presenting stronger correlations (Pearson correlation) with the ordination axes: $\mathrm{pH}, \mathrm{P}$, $\mathrm{Na}, \mathrm{Ca}, \mathrm{Al}, \mathrm{H}+\mathrm{Al}$ (acidity) and amount of organic matter. A Monte Carlo permutation test (1000 permutations) was applied to verify the significance of the correlations between the species and environmental variables.

\section{Results and discussion}

A total of 35 species belonging to 20 families was surveyed in the three restinga areas of Piauí (Tab. 1). It is noteworthy that Caesalpinia pyramidalis, Copaifera martii and Maytenus distichophylla were present in all three of the areas sampled.

In the Ilha Grande area, we sampled 12 species from nine botanical families (Tab. 1). Anacardium occidentale was the predominant species $(\mathrm{IV}=21.55 \%)$, with the highest density

Table 1. Phytosociological parameters of the three areas of restinga (coastal woodland) vegetation studied in the Parnaíba Delta Protected Area, state of Piauí, Brazil.

\begin{tabular}{|c|c|c|c|c|c|c|c|c|c|c|c|c|c|c|c|c|c|c|c|c|c|c|}
\hline \multirow[t]{2}{*}{ Species } & \multirow[t]{2}{*}{$\begin{array}{l}\text { Abbrev. } \\
\text { (spp.) }\end{array}$} & \multicolumn{7}{|c|}{$\begin{array}{c}\text { Area I } \\
\text { (Ilha Grande) }\end{array}$} & \multicolumn{7}{|c|}{$\begin{array}{c}\text { Area II } \\
\text { (Parnaíba) }\end{array}$} & \multicolumn{7}{|c|}{$\begin{array}{c}\text { Area III } \\
\text { (Luiz Correia) }\end{array}$} \\
\hline & & $\mathrm{N}$ & $\mathrm{RD}$ & RDo & $\mathrm{RF}$ & IV & $\mathrm{CV}$ & BA & $\mathrm{N}$ & $\mathrm{RD}$ & RDo & $\mathrm{RF}$ & IV & $\mathrm{CV}$ & $\mathrm{BA}$ & $\mathrm{N}$ & $\mathrm{RD}$ & RDo & RF & IV & $\mathrm{CV}$ & $\mathrm{BA}$ \\
\hline Anacardium occidentale L. & Ana occ & 38 & 19.0 & 29.1 & 16.55 & 21.55 & 24.06 & 0.481 & - & - & - & - & - & - & - & 2 & 1.00 & 7.03 & 1.56 & 3.2 & 4.01 & 0.276 \\
\hline Astrocaryum vulgare Mart. & Ast vul & 3 & 1.5 & 3.39 & 2.07 & 2.32 & 2.44 & 0.056 & - & - & - & - & - & - & - & - & - & - & - & - & - & - \\
\hline Byrsonima gardneriana A. Juss. & Byr gar & 22 & 11.0 & 3.85 & 11.03 & 8.63 & 7.43 & 0.064 & - & - & - & - & - & - & - & 3 & 1.50 & 3.41 & 2.34 & 2.41 & 2.46 & 0.133 \\
\hline Byrsonima verbascifolia (L.) DC & Byr ver & - & - & - & - & - & - & - & 3 & 1.50 & 0.87 & 0.69 & 1.02 & 1.185 & 0.012 & - & - & - & - & - & - & - \\
\hline Caesalpinia ferrea Mart. & Cae fer & - & - & - & - & - & - & - & - & - & - & - & - & - & - & 1 & 0.50 & 0.21 & 0.78 & 0.49 & 0.355 & 0.008 \\
\hline Caesalpinia pyramidalis Benth. & Cae pyr & 20 & 10.0 & 6.23 & 10.34 & 8.86 & 8.11 & 0.103 & 43 & 21.50 & 34.74 & 15.17 & 23.82 & 28.12 & 0.493 & 87 & 43.50 & 29.67 & 34.38 & 35.87 & 736.59 & 1.162 \\
\hline $\begin{array}{l}\text { Campomanesia aromatica } \\
\text { (Aubl.) Griseb. }\end{array}$ & Cam aro & 7 & 3.5 & 1.67 & 3.45 & 2.87 & 2.58 & 0.028 & - & - & - & - & - & - & - & - & - & - & - & - & - & - \\
\hline Cereus jamacaru DC. & Cer Jam & 29 & 14.5 & 25.33 & 315.86 & 18.56 & 19.92 & 0.419 & - & - & - & - & - & - & - & - & - & - & - & - & - & - \\
\hline
\end{tabular}


Table 1. Continuation

\begin{tabular}{|c|c|c|c|c|c|c|c|c|c|c|c|c|c|c|c|c|c|c|c|c|c|c|}
\hline \multirow[t]{2}{*}{ Species } & \multirow{2}{*}{$\begin{array}{l}\text { Abbrev. } \\
\text { (spp.) }\end{array}$} & \multicolumn{7}{|c|}{$\begin{array}{c}\text { Area I } \\
\text { (Ilha Grande) }\end{array}$} & \multicolumn{7}{|c|}{$\begin{array}{c}\text { Area II } \\
\text { (Parnaíba) }\end{array}$} & \multicolumn{7}{|c|}{$\begin{array}{c}\text { Area III } \\
\text { (Luiz Correia) }\end{array}$} \\
\hline & & $\mathrm{N}$ & $\mathrm{RD}$ & RDo & $\mathrm{RF}$ & IV & $\mathrm{CV}$ & BA & $\mathrm{N}$ & $\mathrm{RD}$ & RDo & $\mathrm{RF}$ & IV & $\mathrm{CV}$ & $\mathrm{BA}$ & $\mathrm{N}$ & $\mathrm{RD}$ & RDo & RF & IV & $\mathrm{CV}$ & $\mathrm{BA}$ \\
\hline Chamaecrista sp. & Cham sp & - & - & - & - & - & - & - & - & - & - & - & - & - & - & 2 & 1.00 & 0.10 & 1.56 & 0.88 & 0.55 & 50.004 \\
\hline Combretum leprosum Mart. & Com lep & - & - & - & - & - & - & - & 6 & 3.00 & 2.54 & 3.45 & 2.99 & 2.77 & 0.036 & - & - & - & - & - & - & - \\
\hline Copaifera martii Hayne & Cop mar & 11 & 5.5 & 3.75 & 6.21 & 5.15 & 4.62 & 0.062 & 26 & 13.00 & 8.46 & 12.41 & 11.29 & 10.73 & 0.120 & 14 & 7.00 & 16.45 & 8.59 & 10.68 & 311.73 & 30.645 \\
\hline Cordia rufescens A.DC. & Cor ruf & - & - & - & - & - & - & - & - & - & - & - & - & - & - & 2 & 1.00 & 0.20 & 1.56 & 0.92 & 0.60 & 0.008 \\
\hline Eugenia punicifolia (Kunth) DC. & Eug pun & 11 & 5.5 & 6.62 & 5.52 & 5.88 & 6.06 & 0.109 & 4 & 2.00 & 0.50 & 2.76 & 1.75 & 1.25 & 0.007 & - & - & - & - & - & - & - \\
\hline $\begin{array}{l}\text { Ficus gomeleira Kunth } \\
\text { \& C.D. Bouché }\end{array}$ & Fic gom & - & - & - & - & - & - & - & 1 & 0.50 & 0.58 & 0.69 & 0.59 & 0.54 & 0.008 & - & - & - & - & - & - & - \\
\hline Guettarda platypoda DC. & Gue pla & - & - & - & - & - & - & - & 7 & 3.50 & 3.12 & 4.14 & 3.58 & 3.31 & 0.044 & 3 & 1.50 & 0.20 & 2.34 & 1.34 & 0.85 & 50.008 \\
\hline Jatropha mollissima Baill. & Jat mol & - & - & - & - & - & - & - & - & - & - & - & - & - & - & 16 & 8.00 & 1.51 & 6.25 & 5.25 & 4.755 & 50.059 \\
\hline Lantana camara $\mathrm{L}$. & Lan cam & - & - & - & - & - & - & - & 3 & 1.50 & 0.91 & 2.07 & 1.49 & 1.205 & 0.013 & - & - & - & - & - & - & - \\
\hline $\begin{array}{l}\text { Maclura tinctoria (L.) } \\
\text { D. Don ex Steud. }\end{array}$ & Mac tin & - & - & - & - & - & - & - & - & - & - & - & - & - & - & 3 & 1.50 & 1.05 & 1.56 & 1.37 & 1.275 & 50.041 \\
\hline $\begin{array}{l}\text { Manilkara salzmannii } \\
\text { (A.DC.) H. J. Lam }\end{array}$ & Man sal & - & - & - & - & - & - & - & 2 & 1.00 & 0.82 & 1.38 & 1.07 & 0.91 & 0.012 & - & - & - & - & - & - & - \\
\hline $\begin{array}{l}\text { Manilkara triflora } \\
\text { (Allemão) Monach. }\end{array}$ & Man tri & - & - & - & - & - & - & - & 7 & 3.50 & 1.17 & 4.83 & 3.172 & 2.335 & 0.017 & 1 & 0.50 & 2.59 & 0.78 & 1.29 & 1.545 & 50.102 \\
\hline Maytenus distichophylla Mart. & May dis & 10 & 5.0 & 1.88 & 4.14 & 3.67 & 3.44 & 0.031 & 7 & 3.50 & 1.60 & 4.83 & 3.31 & 2.55 & 0.023 & 8 & 4.00 & 10.56 & 65.47 & 6.67 & 7.28 & 80.414 \\
\hline Mimosa caesalpiniaefolia Benth. & Mim cae & - & - & - & - & - & - & - & - & - & - & - & - & - & - & 24 & 12.0 & 7.48 & 12.50 & 10.66 & 59.74 & 40.293 \\
\hline Mimosa ophtalmocentra Mart. & Mim oph & - & - & - & - & - & - & - & 16 & 8.00 & 3.07 & 8.97 & 6.685 & 5.535 & 0.044 & 2 & 1.00 & 0.75 & 1.56 & 1.11 & 0.875 & 50.030 \\
\hline $\begin{array}{l}\text { Mimosa tenuiflora } \\
\text { (Willd.) Poir. }\end{array}$ & Mim tem & - & - & - & - & - & - & - & 28 & 14.00 & 25.65 & 13.79 & $17.81 \mathrm{l}$ & 19.83 & 0.364 & - & - & - & - & - & - & - \\
\hline Mouriri pusa Gardner & Mou pus & 1 & 0.5 & 0.07 & 0.69 & 0.42 & 0.28 & 0.001 & - & - & - & - & - & - & - & 1 & 0.50 & 0.03 & 0.78 & 0.44 & 0.265 & 50.001 \\
\hline Myrcia splendens (Sw.) DC. & Myr spl & 13 & 6.50 & 9.31 & 6.90 & 7.57 & 7.90 & 0.154 & - & - & - & - & - & - & - & 6 & 3.00 & 0.63 & 4.69 & 2.77 & 1.815 & 50.025 \\
\hline $\begin{array}{l}\text { Ouratea fieldingiana } \\
\text { (Gardner) Engl. }\end{array}$ & Our fie & 35 & 17.5 & 8.82 & 17.24 & 14.521 & 13.16 & 0.146 & - & - & - & - & - & - & - & - & - & - & - & - & - & - \\
\hline $\begin{array}{l}\text { Peltogyne confertiflora } \\
\text { (Mart. ex Hayne) Benth. }\end{array}$ & Pel con & - & - & - & - & - & - & - & 16 & 8.00 & 5.69 & 9.66 & 7.78 & 6.845 & 0.081 & 5 & 2.50 & 0.53 & 2.34 & 1.79 & 1.515 & 50.021 \\
\hline Piptadenia moniliformis Benth. & Pip mon & - & - & - & - & - & - & - & 7 & 3.50 & 2.57 & 4.14 & 3.4 & 3.03 & 0.036 & 5 & 2.50 & 0.29 & 2.34 & 1.71 & 1.395 & 50.011 \\
\hline $\begin{array}{l}\text { Senna trachypus (Mart. ex } \\
\text { Benth.) H.S. Irwin \& Barneby }\end{array}$ & Sen tra & - & - & - & - & - & - & - & - & - & - & - & - & - & - & 6 & 3.00 & 0.96 & 3.13 & 2.36 & 1.98 & 80.038 \\
\hline Solanum paludosum Moric. & Sol pal & - & - & - & - & - & - & - & 20 & 10.0 & 5.09 & 8.28 & 7.797 & 7.545 & 0.072 & 3 & 1.50 & 0.14 & 1.56 & 1.1 & 0.82 & 20.005 \\
\hline $\begin{array}{l}\text { Tocoyena sellowiana } \\
\text { (Cham. \& Schltdl.) K. Schum. }\end{array}$ & Toc sel & - & - & - & - & - & - & - & 3 & 1.50 & 2.54 & 2.07 & 2.04 & 2.02 & 0.036 & - & - & - & - & - & - & - \\
\hline Ziziphus joazeiro Mart. & Ziz joa & - & - & - & - & - & - & - & - & - & - & - & - & - & - & 3 & 1.50 & 8.14 & 1.56 & 3.73 & 4.82 & 20.319 \\
\hline Desconhecida 1 & Desc 1 & - & - & - & - & - & - & - & 1 & 0.50 & 0.08 & 0.69 & 0.42 & 0.29 & 0.001 & 1 & 0.50 & 7.49 & 0.78 & 2.92 & 3.995 & 50.293 \\
\hline Desconhecida 2 & Desc 2 & - & - & - & - & - & - & - & - & - & - & - & - & - & - & 2 & 1.00 & 0.56 & 1.56 & 1.04 & 0.78 & 80.022 \\
\hline
\end{tabular}

and relative dominance, followed by Cereus jamacaru (IV $=18.56 \%)$, Ouratea fieldingiana (IV = 14.52\%), Caesalpinia pyramidalis (IV $=8.86 \%)$ and Byrsonima gardneriana $(\mathrm{IV}=8.63 \%)$. Copaifera martii and Maytenus distichophylla were also present (IV $=5.15 \%$ and $3.67 \%$, respectively). Ouratea fieldingiana had the highest relative frequency (17.24\%), and the family Myrtaceae presented the most species $(22.2 \%)$. We found that $85 \%$ of the sampled indi- viduals presented a DGL $\leq 13 \mathrm{~cm}$ (Fig. 2), whereas only $2 \%$ of the sample presented a DGL $>33.1 \mathrm{~cm}$ (maximum, $43 \mathrm{~cm}$ ). In terms of height, the restinga of Ilha Grande was characterised as a low fruit grove, more than $80 \%$ of its sampled plants being $\leq 2 \mathrm{~m}$ in height (Fig. 3).

In the Parnaíba area, more than $88 \%$ of the sampled individuals presented a DGL $\leq 13 \mathrm{~cm}$ (Fig. 4). The sampled individuals were similar those of Ilha Grande in terms of 


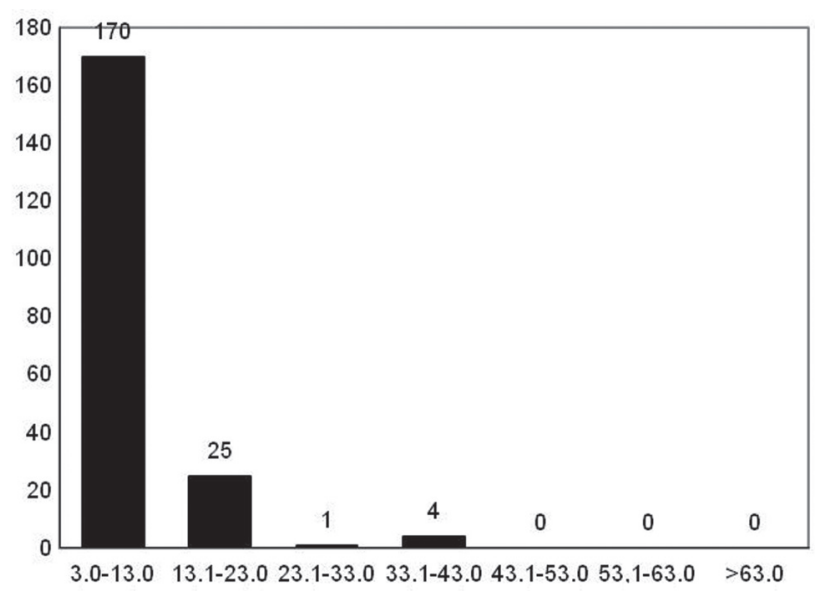

Figure 2. Distribution of the diameters at ground level, by category, among the woody plant individuals sampled in an area of restinga (coastal woodland) vegetation near the municipality of Ilha Grande, state of Piauí, Brazil.

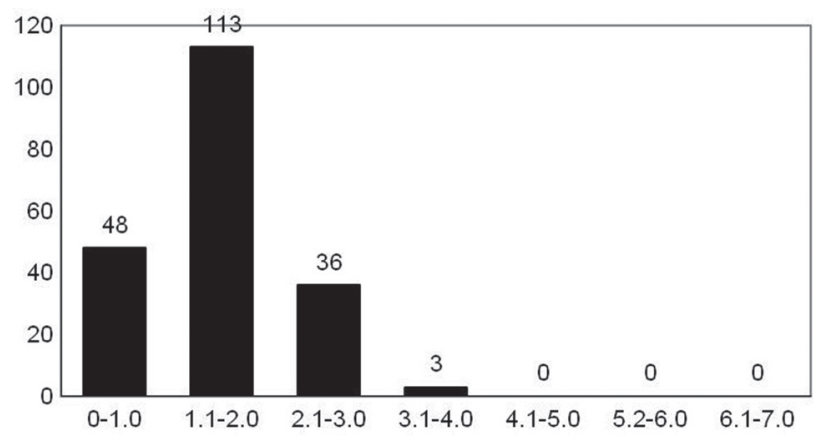

Figure 3. Distribution of heights, by category, among woody plant individuals sampled in an area of restinga (coastal woodland) vegetation near the municipality of Ilha Grande, state of Piauí, Brazil.

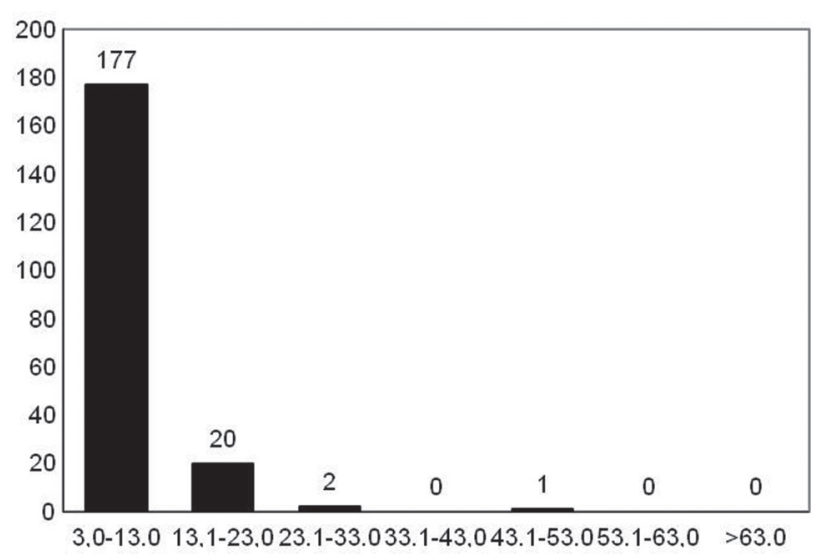

Figure 4. Distribution of the diameters at ground level, by category, among woody plant individuals sampled in an area of restinga (coastal woodland) vegetation near the municipality of Parnaíba, state of Piauí, Brazil.

height, $88 \%$ of the plants being $1-3 \mathrm{~m}$ in height (Fig. 5). In this restinga, we observed a fruit grove with 18 species from 11 families. Three species predominated: Caesalpinia pyramidalis (IV = 23.82\%); Mimosa tenuiflora (IV = 17.81\%); and Copaifera martii (IV = 11.29\%). Maytenus distichophylla was also present $(\mathrm{IV}=3.31 \%)$.

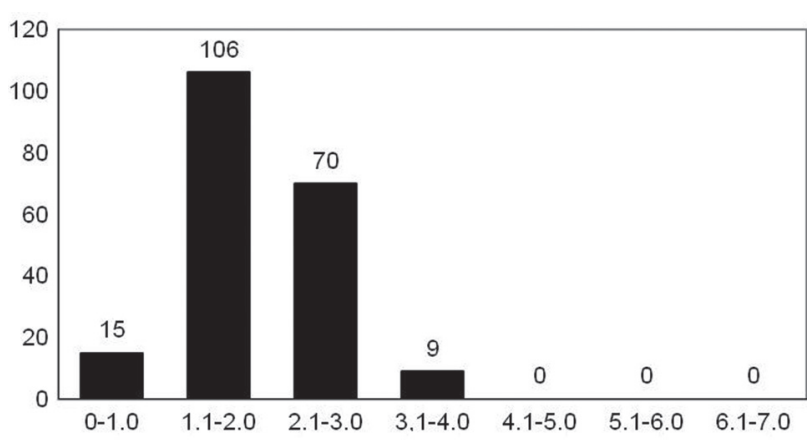

Figure 5. Distribution of heights, by category, among woody plant individuals sampled in an area of restinga (coastal woodland) vegetation near the municipality of Parnaíba, state of Piauí, Brazil.

In the Luiz Correia area, $74 \%$ of the sampled individuals presented a DGL $\leq 13 \mathrm{~cm}$ and $3 \%$ of the species had a DG $>53 \mathrm{~cm}$ (Fig. 6). In addition, $75.5 \%$ of the woody vegetation was $2.01-4 \mathrm{~m}$ in height (Fig. 7 ), 3.5\% of the plants being $>5 \mathrm{~m}$ in height. The restinga of the area was characterised as a forest, dominated by the species Caesalpinia pyramidalis $(\mathrm{IV}=35.87 \%)$, Copaifera martii $(\mathrm{IV}=10.68 \%)$ and Mimosa caesalpiniaefolia (IV = 10.66\%). Maytenus distichophylla was also present $(\mathrm{IV}=6.67 \%)$. C. pyramidalis prevailed in all of the component parameters of IV (relative density $=$ $43.50 \%$; relative dominance $=29.67 \%$ and relative frequency $=34.38 \%$ ). In this restinga, 23 species from 15 families were represented. As in Parnaíba, the Fabaceae family (Leguminosae, l.s.) accounted for the largest proportion (39.1\%) of the species sampled.

In terms of height, the studied restingas presented different results. In the restinga of Ilha Grande, most of the sampled individuals presented heights concentrated in the $<1.0 \mathrm{~m}$ and 1.1-2.0 $\mathrm{m}$ categories (Fig. 3). The individuals in the Parnaíba restinga were taller, most being in the $1.1-2.0 \mathrm{~m}$ and 2.1-3.0 m height categories (Fig. 5). In contrast, individuals in the restinga of Luiz Correia were in the 2.1-3.0 m and 3.1-4.0 $\mathrm{m}$ height categories (Fig. 7).

The values of H' and J' for the three sampled areas are shown in Tab. 2. The Hutcheson t-test indicated that the Shannon diversity indices for the three areas were significantly different (Tab. 3).

Physical analysis of the soil showed a high (over 90\%) sand content (Tab. 4). The variables differed significantly within the Parnaíba and Luiz Correia areas. The textural analysis confirmed that the three soils are sandy, corroborating the geologic classification (BRAZIL 2006).

The chemical analysis of the soil revealed that the restinga areas of the Piauí coast presented sandy soils with $\mathrm{pH}$ varying from acidic (5.62) to alkaline (8.34). Analysis of the variance of nutrients demonstrated significant differences between the areas for all of the nutrients evaluated, except for $\mathrm{K}^{+}$, which was found in the soil of all three areas (Tab. 4).

The CCA (Fig. 8) allowed us to verify that some variables significantly contributed to separation between the areas 


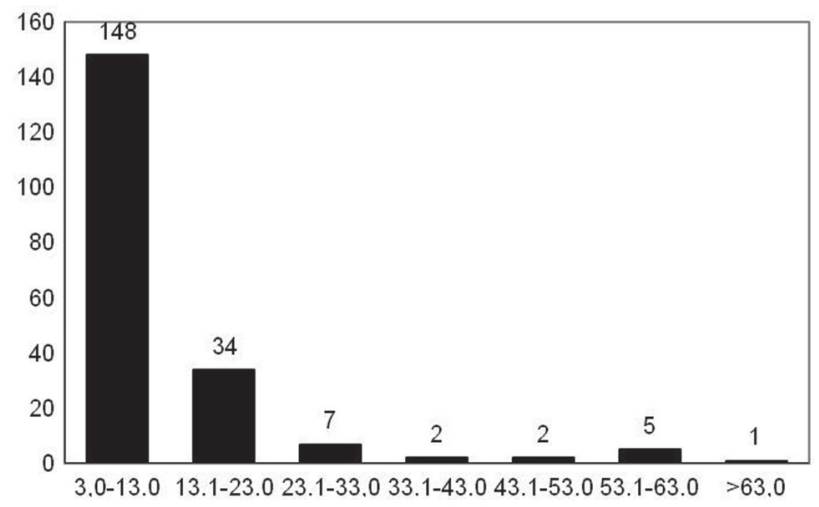

Figure 6. Distribution of the diameters at ground level, by category, among woody plant individuals sampled in an area of restinga (coastal woodland) vegetation near the municipality of Luiz Correia, state of Piauí, Brazil.

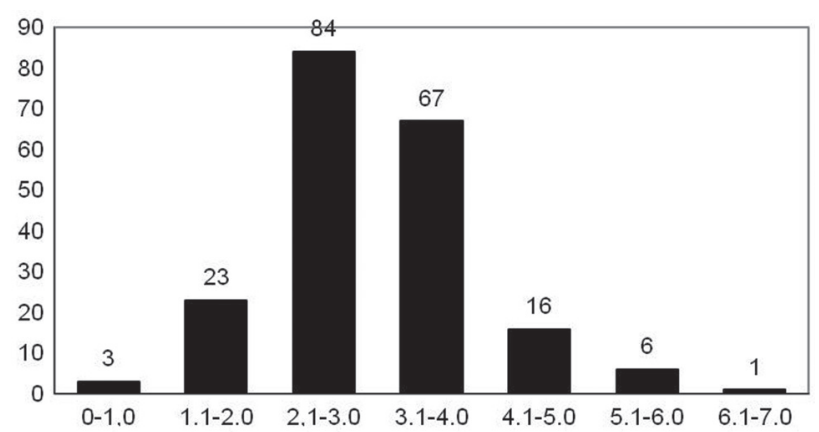

Figure 7. Distribution of heights, by category, among woody plant individuals sampled in an area of restinga (coastal woodland) vegetation near the municipality of Luiz Correia, state of Piauí, Brazil.
Table 2. Diversity and evenness indices of the three areas of restinga (coastal woodland) vegetation studied in the Parnaiba Delta Protected Area, state of Piauí, Brazil.

\begin{tabular}{|c|c|c|c|}
\hline Index Restinga & $\begin{array}{c}\text { Area I } \\
\text { (Ilha Grande) }\end{array}$ & $\begin{array}{c}\text { Area II } \\
\text { (Parnaíba) }\end{array}$ & $\begin{array}{c}\text { Area III } \\
\text { (Luiz Correia) }\end{array}$ \\
\hline $\mathrm{H}^{\prime}$ & 2.227 & 2.446 & 2.180 \\
\hline$J^{\prime}$ & 0.896 & 0.846 & 0.695 \\
\hline
\end{tabular}

H' - Shannon diversity index; J' - Pielou's evenness index.

Table 3. Comparison among the Shannon diversity indices of the three areas of restinga (coastal woodland) vegetation studied in the Parnaíba Delta Protected Area, state of Piauí, Brazil, with the Hutcheson test $(\alpha=1 \%$; $<<0.05)$.

\begin{tabular}{lcc} 
Restinga & $\begin{array}{c}\text { Area II } \\
\text { (Parnaíba) }\end{array}$ & $\begin{array}{c}\text { Area III } \\
\text { (Luiz Correia) }\end{array}$ \\
\hline Area I (Ilha Grande) & 0.5993 & 0.112 \\
Area II (Parnaíba) & - & 0.6819 \\
\hline
\end{tabular}

Table 4. Chemical and textural variables of the composite samples of superficial soil (0-20 cm of depth) randomly collected from transects of the three areas of restinga (coastal woodland) vegetation studied in the Parnaíba Delta Protected Area, state of Piauí, Brazil.

\begin{tabular}{|c|c|c|c|c|c|}
\hline \multirow{2}{*}{ Edaphic variables } & \multicolumn{2}{|c|}{$\begin{array}{l}\text { ANOVA } \\
\text { (Ilha Grande) }\end{array}$} & \multirow{2}{*}{$\begin{array}{c}\text { Area I } \\
\text { (Parnaíba) } \\
\mathrm{n}=5\end{array}$} & \multirow{2}{*}{$\begin{array}{c}\begin{array}{c}\text { Area II } \\
\text { (Luiz Correia) } \\
\mathrm{n}=5\end{array} \\
\end{array}$} & \multirow{2}{*}{$\begin{array}{l}\text { Area III } \\
n=5\end{array}$} \\
\hline & $\mathrm{F}$ & (p) & & & \\
\hline $\mathrm{pH}$ in $\mathrm{H}_{2} \mathrm{O}$ & 170.022 & 0.001 & $5.62 \pm 0.228$ & $6.18 \pm 0.192$ & $8.34 \pm 0.305$ \\
\hline $\mathrm{P}\left(\mathrm{mg} / \mathrm{dm}^{3}\right)$ & 36.662 & 0.0000 & $4.00 \pm 0.71$ & $6.80 \pm 2.59$ & $15.2 \pm 2.59$ \\
\hline $\mathrm{Na}^{+}\left(\mathrm{cmol}_{\mathrm{c}} / \mathrm{dm}^{3}\right)$ & 46.71 & 0.0000 & $0.034 \pm 0.005$ & $0.058 \pm 0.008$ & $0.012 \pm 0.008$ \\
\hline $\mathrm{K}^{+}\left(\mathrm{cmol}_{\mathrm{c}} / \mathrm{dm}^{3}\right)$ & 3.323 & $0.007^{\mathrm{ns}}$ & $0.03 \pm 0.012$ & $0.042 \pm 0.018$ & $0.054 \pm 0.013$ \\
\hline $\mathrm{Ca}^{2+}+\mathrm{Mg}^{2+}\left(\mathrm{cmol}_{\mathrm{c}} / \mathrm{dm}^{3}\right)$ & 47.31 & 0.0000 & $0.61 \pm 0.096$ & $3.01 \pm 0.799$ & $4.19 \pm 0.639$ \\
\hline $\mathrm{Ca}^{2+}\left(\mathrm{cmol}_{\mathrm{c}} / \mathrm{dm}^{3}\right)$ & 44.33 & 0.0000 & $0.14 \pm 0.21$ & $2.12 \pm 0.688$ & $3.05 \pm 0.481$ \\
\hline $\mathrm{Al}^{3+}\left(\mathrm{cmol}_{\mathrm{c}} / \mathrm{dm}^{3}\right)$ & - & - & $0.23 \pm 0.067$ & 0.00 & 0.00 \\
\hline $\mathrm{H}+\mathrm{Al}\left(\mathrm{cmol}_{\mathrm{c}} / \mathrm{dm}^{3}\right)$ & 69.34 & 0.0000 & $2.17 \pm 0.062$ & $2.062 \pm 0.071$ & $1.69 \pm 0.067$ \\
\hline CTC $\left(\mathrm{cmol}_{\mathrm{c}} / \mathrm{dm}^{3}\right)$ & 32.2 & 0.0001 & $2.84 \pm 0.074$ & $5.17 \pm 0.853$ & $5.95 \pm 0.696$ \\
\hline $\mathrm{C}(\mathrm{g} / \mathrm{kg})$ & 10.1 & 0.003 & $2.56 \pm 0.492$ & $5.73 \pm 1.529$ & $3.28 \pm 1.24$ \\
\hline $\mathrm{OM}(\mathrm{g} / \mathrm{kg})$ & 10.09 & 0.003 & $4.41 \pm 0.85$ & $9.88 \pm 2.637$ & $5.66 \pm 2.13$ \\
\hline Sand (\%) & - & - & 97.1 & $93.3 \pm 0.91$ & $95.7 \pm 1.342$ \\
\hline Clay (\%) & - & - & 2.9 & $4.6 \pm 0.89$ & $3.7 \pm 0.837$ \\
\hline Silt (\%) & - & - & 0.0 & $2.1 \pm 0.22$ & $0.40 \pm 0.548$ \\
\hline Textural classification & - & - & Sandy & Sandy & Sandy \\
\hline
\end{tabular}

ns - not significant; CTC - cation exchange capacity; OM - organic material. 


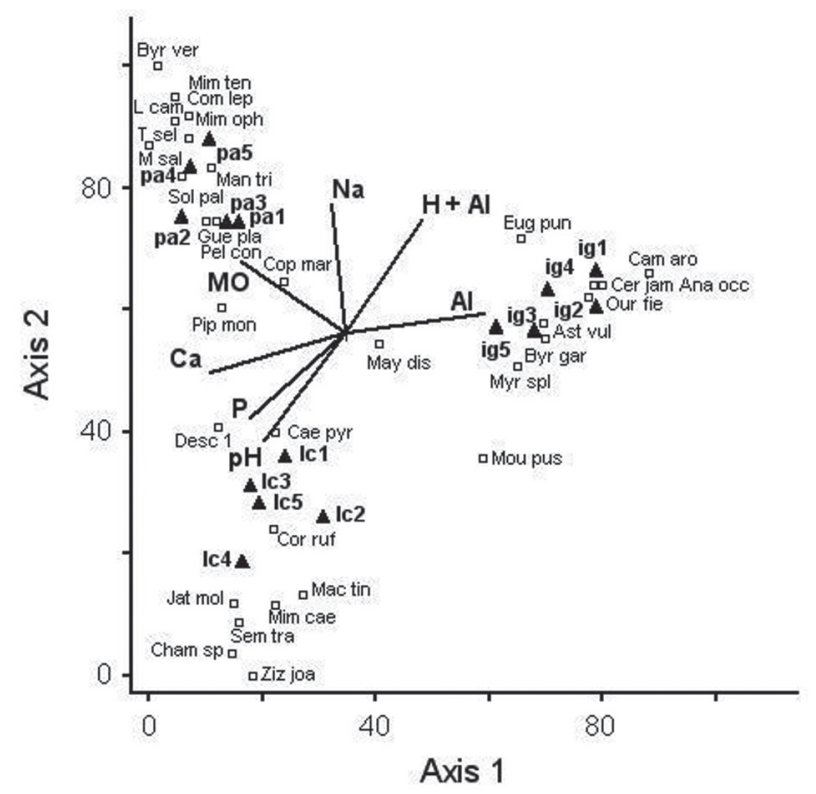

Figure 8. Diagram of the ordination of transects based on the frequency of species in areas of restinga (coastal woodland) near the municipalities of Ilha Grande (ig), Luis Correia (lc) and Parnaíba (pa), state of Piauí, Brazil, and its correlation with the environmental variables evaluated.

$\mathrm{H}+\mathrm{Al}$ - acidity; $\mathrm{OM}$ - organic matter.; Ana occ - Anacardium occidentale; Ast vul - Astrocarium vulgare; Byr gar - Byrsonima gardneriana; Byr ver - Byrsonima verbascifolia; Cae fer - Caesalpinia ferrea; Cae pyr - Caesalpinia pyramidalis; Cam aro - Campomanesia aromática; Cer Jam - Cereus jamacaru; Cham sp. - Chamaecrista sp.; Com lep - Combretum leprosum; Cop mar - Copaifera martii; Cor ruf - Cordia rufescens; Eug pun - Eugenia punicifolia; Fic gom Ficus gomeleira; Gue pla - Guettarda platypoda; Jat mol - Jatropha mollissima; Lan cam - Lantana camara; Mac tin - Maclura tinctoria; Man sal - Manilkara salzmannii; Man tri - Manilkara triflora; May dis - Maytenus distichophylla; Mim cae - Mimosa caesalpiniaefolia; Mim oph - Mimosa ophtalmocentra; Mim tem - Mimosa tenuiflora; Mou pus - Mouriri pusa; Myr spl - Myrcia splendens; Our fie - Ouratea fieldingiana; Pel con - Peltogyne confertiflora; Pip mon - Piptadenia moniliformis; Sen tra - Senna trachypus; Sol pal - Solanum paludosum; Toc sel - Tocoyena sellowiana; Ziz joa - Ziziphus joazeiro; Desc. 1 - Desconhecida 1; Desc. 2 - Desconhecida 2.

and their typical species. Strong evidence in Ilha Grande showed that species developed in the presence of $\mathrm{Al}$ in both the ionic $\left(\mathrm{Al}^{3-}\right)$ and associated forms (value $\mathrm{m}: \mathrm{H}+\mathrm{Al}$ ). Elevated values of $\mathrm{P}$ and $\mathrm{pH}$ contributed to the separation of species present in the region of Luiz Correia. The same occurred for species from Parnaíba, but these were also characterised by higher amounts of organic matter (Fig. 8).

The eigenvalues for the two main axes of the CCA (axis 1 and axis 2 ) were 0.687 and 0.389 , respectively. According to Ter Braak (1995), that axis 1 value would be considered high (>0.5). Elevated axis 1 values indicate the existence of long gradients, with various substitutions of species between the two extremities. Values $<0.5$, as for our axis 2 , indicate short gradients where most of the species are distributed throughout the entire gradient (Carvalho et al. 2005b). The environmental variables for which the correlations with axis 1 were the strongest were (in descending order) $\mathrm{H}+\mathrm{Al}, \mathrm{Ca}$, $\mathrm{Al}$ and $\mathrm{pH}$, whereas the same for axis 2 were $\mathrm{H}+\mathrm{Al}, \mathrm{Ca}, \mathrm{Na}$ and the amount of organic matter (Tab. 5).
Table 5. Coefficients of correlation among the edaphic variables and the two first axes of ordination of the canonical correspondence analysis, obtained in three areas of restinga (coastal woodland) vegetation studied in the Parnaíba Delta Protected Area, state of Piauí, Brazil.

\begin{tabular}{lcc}
\hline Edaphic variable & Axis 1 & Axis 2 \\
\hline $\mathrm{pH}$ & -0.124 & -0.250 \\
$\mathrm{P}$ & -0.403 & -0.113 \\
$\mathrm{Na}$ & -0.888 & 0.186 \\
$\mathrm{Ca}$ & 0.529 & 0.267 \\
$\mathrm{Al}$ & 0.315 & -0.215 \\
$\mathrm{H}+\mathrm{Al}$ & 0.945 & 0.515 \\
$\mathrm{OM}$ & -0.345 & 0.021 \\
\hline
\end{tabular}

$\mathrm{OM}$ - organic material.

In the Ilha Grande restinga, the Myrtaceae family had the largest number of species. Species of this family are often found in samplings of restingas in the northeastern state of Rio Grande do Norte (Trindade 1991; Almeida Jr. \& Zickel 2012), as well as in restingas and areas of Atlantic Forest in the southeastern region of the country (Pereira et al. 2001; Assis et al. 2004).

In the Parnaíba restinga, Fabaceae (Leguminosae, l.s.) predominated and was the family with the highest proportion of representatives in this sample (33.3\%). Several studies have reported that Fabaceae is one of the most common families in restingas of the northeast (Cantarelli 2003; Sacramento et al. 2007; Silva et al. 2008; Almeida Jr. et al. 2009) and southeast (Araújo \& Henriques 1984; Silva \& Oliveira 1989; Sá 1992; Araújo 2000; Lemos et al. 2001), because it has common representatives in the neotropical flora (Gentry 1988). The Parnaíba restinga presented the highest $H$ 'value, ranging from 1.3 to 4.0. According to Kent \& Coker (1994) and Felfili \& Rezende (2003), these H' values are relatively low. Tab. 6 shows data on the species richness of the studied restingas (Santos-Filho 2009), as compared with that of other northeastern restingas, demonstrating a substantial number of species, despite the low H'values.

In the Brazilian caatinga (shrublands), Caesalpinia pyramidalis and Copaifera martii are among the most common species (Giulietti et al. 2002; Queiroz et al. 2006), although they are not commonly found in the northeastern restingas. The low rainfall of the region likely contributes to this distinction, as the time of precipitation and space variations influence the distribution patterns of native plants (Augustine 2010). Although the average annual rainfall amounts are higher in the restingas than in caatinga, the uneven distribution of precipitation and low seasonal rainfall indices have detrimental effects, leading to phenomena such as shedding in the drier months (Fernandes et al. 1996). Those plant characteristics allowed the authors to classify habitats of Piauí restingas as part of the Northern Sertaneja Depression (Velloso et al. 2002) with vegetation consisting of extensive caatinga (Ab'Saber 2006). Geomorphologically, 
Table 6. Plant diversity in various restingas (coastal woodlands) in northeast Brazil.

\begin{tabular}{lccc}
\hline Restinga & Families & Species & Reference \\
\hline São Luiz, MA & 60 & 200 & Freire \& Monteiro (1994) \\
Jericoacoara Protected Area, CE & 41 & 87 & Matias \& Nunes (2001) \\
Dunas State Park, RN & 78 & 264 & Freire (1990) \\
Pipa Ecological Reserve, RN & 62 & 168 & Almeida Jr. et al. (2006) \\
Mataraca, PB & 73 & 263 & Oliveira Filho \& Carvalho (1993) \\
Praia do Paiva, PE & 55 & 124 & Sacramento et al. (2007) \\
Ariquindá, PE & 54 & 104 & Silva et al. (2008) \\
Serrambi, PE & 71 & 186 & Almeida Jr. \& Zickel (2009) \\
Boa Viagem, PE & 21 & 39 & Andrade-Lima (1951) \\
Maceió, AL & 30 & 68 & Esteves (1980) \\
Ilha Grande, PI & 27 & 58 & Santos-Filho (2009) \\
Parnaíba, PI & 40 & 131 & Santos-Filho (2009) \\
Luiz Correia, PI & 50 & 116 & Santos-Filho (2009) \\
\hline
\end{tabular}

MA - Maranhão; CE - Ceará; RN - Rio Grande do Norte; PB - Paraíba; PE - Pernambuco; AL - Alagoas; PI - Piauí.

the studied areas are sand deposits from the Quaternary and the plant composition is similar to that of other northeastern restingas. These areas are also similar to the Atlantic Forest, by extension, especially when considering those occurring within areas of transition from cerrado (savanna) to caatinga and areas of transition to Amazon rain forest.

Considering all three of the studied areas as a whole, we found that $82.5 \%$ of the samples showed a DGL $\leq 13 \mathrm{~cm}$. Therefore, the individuals of these areas are in the young phase. In the sampled areas, $42 \%$ of the individuals showed tillering, each plant presenting $\leq 26$ tillers. This high number of tillers suggest that the areas are in a regenerating phase, allowing inference to some degree by human activity (Sztutman \& Rodrigues 2002). This situation has also been reported for other areas of restinga, such as those in the southeast and northeast (Sá 1992; Vicente et al. 2003 and Almeida Jr. et al. 2011). The distribution curves of the DGLs of the individuals in the three areas (Fig. 2, 4 and 6) are presented as an inverted "J". These results suggest a regular distribution of individuals and continuous recruitment to these areas, similar to that observed for the restingas of Pernambuco (Almeida Jr. et al. 2011).

Sugiyama (1998) evaluated two restinga forests on Ilha do Cardoso, and island off the coast of the state of São Paulo, and found 'H' and J' values of 2.44 and 0.71 , respectively, similar to those recorded in the present study. The Ilha do Cardoso restinga is characterised as open, well-illuminated forest with a mid canopy of $5 \mathrm{~m}$ and sandy soil with a thin layer of humus. This area has an $\mathrm{H}^{\prime}$ value equivalent to those found for the restingas of Piauí, indicating equivalency in plant diversity between the coasts of São Paulo and Piauí, especially considering that only woody species were used for calculating the indices. Proximity to human habitats can favour herbaceous species that strongly contribute in the landscape's characteristics (Halvorsen \& Edvardsen
2009). Other studies in restingas of São Paulo revealed higher H' values, ranging from 3.50 to 3.70 (Guedes et al. 2006). Considering woody plants and the same inclusion criterion, the restingas of Piauí presented lower $\mathrm{H}^{\prime}$ values in comparison with other northeastern restingas (Guadalupe, Pernambuco, with 2.64 (Cantarelli 2003), Pipa, Rio Grande do Norte, with 2.76 (Almeida Jr. \& Zickel, not published), Ariquindá, Pernambuco, with 2.85 (Vicente et al. 2003) and Maracaípe, Pernambuco, with 3.5 (Almeida Jr. et al. 2011).

Physical analyses carried out for other restingas also indicated sandy or clear sandy soils. Gomes et al. (1998) analysed seven different restingas and collected samples from different depths. The mean levels of sand were $96 \%$ for depths $\leq 20 \mathrm{~cm}$. In northeastern restingas, the sand level varied from $90.3 \%$ (non-flooded forests) to $98 \%$ (non-flooded fields) (Sacramento et al. 2007).

The chemical analysis of the soil revealed that the restinga areas of the Piauí coast presented sandy soils with $\mathrm{pH}$ values varying from acidic (5.62) to alkaline (8.34). The soil of Ilha Grande presented a higher sand composition, higher acidity and a high deficiency of nutrients when compared with the other samples. These differences might have affected the establishment of the plant community. Survival is limited in acidic soil because of the reduced presence of decomposing organisms (Mohr \& Van Baren 1959; Silva 1990). The heterogeneous distribution of nutrients is a structural factor responsible for these communities (Wijesinghe et al. 2005). The $\mathrm{pH}$ values found in the restinga soils of Piauí were higher than those found in soils of the Pernambuco restinga, in agreement with the higher amounts of organic matter in Pernambuco restingas than in Piauí restingas (Cantarelli 2003). Higher $\mathrm{pH}$ values result from the influence of shell debris from marine sediments (Embrapa 1987), as has also been reported for the coastal woodlands of Australia and South Korea (Bowman 1989; Kim \& Yu 2009). The soil of 
Ilha Grande contained aluminium and low levels of calcium. This suggests that the plants have more difficulty in obtaining water and nutrients, generating a superficial root system (Casagrande 2003), and that herbaceous species are more abundant. The competition between woody plants and herbaceous species can also be explained by other factors, such as high salinity and water saturation (Poulter et al. 2009). The presence of aluminium has a slight connection to a phosphorus deficit. Aluminium causes precipitation of phosphorus in the form of aluminium phosphates, which are insoluble in the soil and root tissue, and thus generate a phosphorus deficit in the plant (Sutcliffe \& Baker 1989). Similar values for aluminium were found in soils of formations where herbaceous species prevail (graminoid formations), such as in the restinga of the municipality of Carapebus, in the state of Rio de Janeiro (Henriques et al. 1986).

Among the soils with lower sand content, the Parnaíba soil was more acidic and consequently showed a higher amount of organic matter, conditions that hinder decomposition processes (Mohr \& Van Baren 1959; Silva 1990). The areas of Parnaíba and Luiz Correia presented higher cation exchange capacity than did the Ilha Grande area. Pires (2001) correlated this increased capacity to the higher clay content of the soil, as verified in the samples from both areas, thereby explaining their better nutrient levels. The areas of restinga of Pernambuco presented acidic soils, with a mean pH of 4.8 (Sacramento et al. 2007; Silva et al. 2008), with lower values for the flooded areas (Cantarelli 2003).

The soils presented a saturation rate for very elevated bases, with means ranging from $22.5 \%$ to $71.1 \%$, demonstrating the small influence of the " $\mathrm{m}$ " value $(\mathrm{H}+\mathrm{Al})$, whose mean varied between $1.69 \mathrm{cmol} / \mathrm{dm}^{3}$ and $2.17 \mathrm{cmol} / \mathrm{dm}^{3}$ (Tab. 5). The " $m$ " value was higher in the restingas of Pernambuco, where it varied from $11.63 \mathrm{cmol}_{c} / \mathrm{dm}^{3}$ to 23.4 $\mathrm{cmol}_{\mathrm{c}} / \mathrm{dm}^{3}$ (Cantarelli 2003; Silva et al. 2008).

The presence of shell debris in the soil, as previously mentioned, led to a higher $\mathrm{pH}$ value for the soils of Luiz Correia, which is the area closest to the sea. Species common to all three areas (Maytenus distichophylla, Copaifera martii and Caesalpinia pyramidalis) or to two of the areas - Parnaíba and Luiz Correia - (Piptadenia moniliformis) were unaffected by any of the edaphic variables evaluated.

The percentage of variance for the species were $29.6 \%$ and $16.7 \%$ for axes 1 and 2, respectively (total accumulated $=46.3 \%$ ), indicating a high amount of remaining variance ("noise") unexplained by the chosen variables (Botrel et al. 2002; Carvalho et al. 2005a., Carvalho et al. 2005b). Nevertheless, the presence of high "noise" is common in vegetation data and does not reduce the significance of the species-environment relationships (Ter Braak 1987; Carvalho et al. 2005a).

The Pearson correlations between the species and environment for these axes were 0.994 (axis 1) and 0.986 (axis 2). These correlations demonstrate that such variables are canonical (Ter Braak 1986) and not influenced by the eleva- ted "noise". These results were confirmed by a Monte Carlo permutation test, indicating that the relationships between the species abundance and the environmental variables were correlated in both axes $(\mathrm{p}<0.01)$.

The correlation analyses demonstrated that some edaphic characters (chemical variables) were important for the arrangement and distribution of the species in the three restingas (Fig. 8). However, factors such as declivity, water table, light availability, temperature and levels of human activity, were not evaluated and these can also influence the disposition of the landscape and the composition of the soil (Kimmins 1987). Further studies are needed in order to confirm the distribution and arrangement of the species in the restingas.

The low concentration of the cations $\left(\mathrm{Ca}^{2+}, \mathrm{K}^{+}, \mathrm{Na}^{+}\right.$and $\mathrm{Mg}^{2+}$ ) corroborate the minimal presence of clay. Negatively charged ions of the clay particles bind to these cations, thereby preventing their leaching due to percolating water in the soil (Taiz \& Zeiger 2003).

The exchangeable elements, especially $\mathrm{Ca}, \mathrm{K}$ and $\mathrm{P}$, presented higher levels in the superficial soils when closer to the sea, which might be due to the influence of marine aerosols (Hay \& Lacerda 1984; Britez 2005). This hypothesis was supported by data for these nutrients in the Luiz Correia area (Tab. 5), which is situated closer to the sea, especially for the $\mathrm{Ca}\left(\mathrm{Ca}^{2+}\right)$ and $\mathrm{P}\left(\mathrm{PO}_{4}^{3-}\right)$ ions, which are among those with the highest absorption power (Larcher 2006).

We conclude that the studied areas have vegetation with structural patterns similar to those of other restingas found in the northeastern coast, although they presented lower diversity indices. Although the diversity of species among the sampled areas showed no variation, differences were observed in some chemical components of the soil, such as $\mathrm{pH}$, amount of organic matter, $\mathrm{Al}, \mathrm{H}+\mathrm{Al}$, and $\mathrm{P}$, and are important for the separation of the species. The correlation analysis demonstrated that these edaphic factors contribute to the species distribution, explaining the variations observed in the communities of the restingas studied.

\section{References}

Ab'Saber, A.N. 2006. Fundamentos da geomorfologia costeira do Brasil Atlântico inter e subtropical. In: Ab'Saber, A.N. Brasil: Paisagens de exceção - O litoral e o pantanal mato-grossense patrimônios básicos. Cotia - SP: Ateliê Editorial. p. 79-119.

Almeida Jr., E. B.; Zickel, C. S.; Pimentel, R. M. M. 2006. Caracterização e espectro biológico da vegetação do litoral arenoso do Rio Grande do Norte. Rev.Geog. UFPE. v.23, n.3, p.45-58.

Almeida Jr., E. B.; Olivo, M. A.; Araújo, E. L.; Zickel, C. S. 2009. Caracterização da vegetação de restinga da RPPN de Maracaípe, Pernambuco, com base na fisionomia, flora, nutrientes do solo e lençol freático. Acta Bot. Bras. 23 (1): 36-48

Almeida Jr., E. B.; Santos-Filho, F. S.; Araújo, E. L.; Zickel, C. S. 2011. Structural characterization of the woody plants in restinga of Brazil. Journal of Ecology and the Natural Environment 3(3): 95-103.

Almeida Jr., E.B. \& Zickel, C.S. 2012. Análise fitossociológica do estrato arbustivo-arbóreo de uma floresta de restinga no Rio Grande do Norte. Agrária, 7(2): 286-291. 
APG II. 2003. An update of the Angiosperm Phylogeny Group classification for the orders and families of flowering plants: APGII. Bot. J. Linn. Soc. 141:399-436.

Araújo, D. S. D. 1984. Comunidades vegetais. In: Lacerda, L.D.; Araújo, D.S.D.; Cerqueira, R.; Turcq, B. (org.), Restingas: origem, estrutura e processos. Niterói - RJ: CEUFF, pp.158.

Araújo, D. S. D. 2000. Análise florística e fitogeográfica das restingas do Estado do Rio de Janeiro. Tese (Doutorado em Ecologia). Programa de Pós-Graduação em Ecologia, Universidade Federal do Rio de Janeiro.

Araújo, D. S. D.; Henriques, R. P. B. 1984. Análise florística das restingas do estado do Rio de Janeiro. In: Lacerda, L. D.; Araújo, D. S. D.; Cerqueira, R.; Turcq, B. (org.), Restingas: origem, estrutura e processos. Niterói - RJ: CEUFF. pp. 159-193.

Assis, A. M.; Pereira, O. J.; Thomaz, L. D. 2004. Fitossociologia de uma floresta de restinga no Parque Estadual Paulo César Vinha, Setiba, município de Guarapari (ES). Revta. Brasileira de Botânica 27(2):349-361.

Augustine, D. J. 2010. Spatial versus temporal variation in precipitation in a semiarid ecosystem. Landscape Ecol 25:913-925.

Baptista, J.G. 1981. Geografia Física do Piauí. Teresina: COMEPI.

Botrel, R.T.; Oliveira Filho, A.T.; Rodrigues, L.A. \& Curi, N. 2002. Influência do solo e topografia sobre as variações da composição florística e estrutura da comunidade arbórea-arbustiva de uma floresta estacional semidecidual em Ingaí, MG. Revt. Bras. Bot. 25: 195-213.

Bowman, G.M. 1989. Podzol development in a Holocene chronosequence. I. Moruya Heads, New South Wales. Australian Journal of Soil Research, 27:607-628.

Britez, R.M. Solos. In: Marques, M.C.M.; Britez, R.M. (orgs.) 2005. História Natural e Conservação da Ilha do Mel. Curitiba: Ed. UFPR. p. 103-123.

Cantarelli, J. R. R. 2003. Flora vascular e caracterização fisionômica de uma restinga da Área de Proteção Ambiental de Guadalupe - Pernambuco. Dissertação (Mestrado em Botânica). Programa de Pós-Graduação em Botânica, Universidade Federal Rural de Pernambuco, Recife.

Carvalho, D. A. C.; Oliveira Filho, A. T.; van den Berg, E.; Fontes, M. A. L.; Vilela, E. A.; Marques, J. J. G. S. M. \& Carvalho, W. A. C. 2005a. Variações florísticas e estruturais do componente arbóreo de uma floresta ombófila alto-montana às margens do rio Grande, Bocaina de Minas, MG, Brasil. Act. Bot. Bras. 19: 91-109.

Carvalho, D. A. C.; Oliveira Filho, A. T.; Vilela, E. A.; Curi, N.; van den Berg, E.; Fontes, M. A. L. \& Botezelli, L. 2005b. Distribuição de espécies arbóreo-arbustivas ao longo de um gradiente de solos e topografia em um trecho de floresta ripária do Rio São Francisco em Três Marias, MG, Brasil. Revt. Bras. Bot. 28: 329-345.

Casagrande, J.C. 2003. Considerações sobre recuperação da fertilidade do solo para áreas degradadas. In: Anais do seminário temático sobre recuperação de áreas degradadas. FAPESP IBt/IBAMA. pp. 92-93.

Cottam, G. \& Curtis, J.T. 1956. The use of distance measures in phytosociological sampling. Ecology, 37:451-460.

EMBRAPA 1987. Serviço Nacional de Levantamento e Conservação de Solos (Rio de Janeiro, RJ). Levantamento semidetalhado de solos, classificação da aptidão agrícola das terras e elaboração do anteprojeto de colonização do projeto Campos Novos do Estado do Rio de Janeiro. Rio de Janeiro: Embrapa-SNLCS/INCRA, Parte I.

EMBRAPA. 1997. Manual de métodos de análise de solo. $2^{\text {a }}$ ed. rev. e atual. Rio de Janeiro: EMBRAPA-CNPS.

Farias, R. R. S.; Castro, A. A. J. F. 2004. Fitossociologia de trechos da vegetação do Complexo Campo Maior, PI, Brasil. Acta. Bot. Bras., 18 (4):949-963.

Felfili, J. M.; Rezende, R. P. 2003. Conceitos e métodos em fitossociologia. Comun. Técn. Florestais - UnB, 5(1):1-68.

Fernandes, A. G.; Lopes, A. S.; Silva, E. V.; Conceição, G. M.; Araújo, M. F. V. 1996. IV - Componentes biológicos: Vegetação. In: CEPRO, Macrozoneamento Costeiro do Estado do Piauí: relatório geoambiental e sócio-econômico. Teresina: Fundação CEPRO. pp. 43-72.

Gentry, A. 1988. Changes in plant community Diversity and Florística composition on environmental and geographical gradients. Annals of the Missouri Botanical Garden, 35:1-34.
Giulietti, A.M.; Harley, R.M.; Queiroz, L.P.; Barbosa, M.R.V.; duBocage Neta, A.L; Figueiredo, M.A. 2002. Espécies endêmicas da Caatinga. In: Sampaio, E.V.S.B.; Giulietti, A.M.; Virgínio, J.; Gamarra-Rojas, C.F.L.(eds.) Vegetação \& Flora da Caatinga. Recife: Associação Plantas do Nordeste-APNE, Centro Nordestino de Informações sobre Plantas - CNIP. pp.103-120.

Gomes, J. B. V.; Resende, M.; Rezende, .S. B; Mendonça, E. S. 1998. Solos de três áreas de restinga. I. Morfologia, caracterização e classificação. Pesquisa agropecuária brasileira. 33(11): 1907-1919.

Guedes, D.; Barbosa, L. M.; Martins, S. E. 2006. Composição florística e estrutura fitossociológica de dois fragmentos de floresta de restinga no município de Bertioga, SP, Brasil. Acta bot. bras., 20(2):299-311.

Halvorsen, R.; Edvardsen, A. 2009. The concept of habitat specificity revisited. Landscape Ecol 24:851-861.

Hay, J. D.; Lacerda, L. D. 1984. Ciclagem de nutrientes no ecossistema de restinga. In: Lacerda, L. D.; Araújo, D. S. D.; Cerqueira, R.; Turcq, B. (org.), Restingas: origem, estrutura e processos. Niterói - RJ: CEUFF. pp.459-475.

Henriques, R. P. B.; Araújo, D. S. D.; Hay, J. D. 1986. Descrição e classificação dos tipos de vegetação da restinga de Carapebus, Rio de Janeiro. Rvta. brasil. Bot. v.9, p.173-189.

Hutcheson, K. A. 1970. A test for comparing diversities based on the Shannon formula. Journal of Theoretical Biology. v. 29, p. 151-154.

Kent, M.; Coker, P. 1994. Vegetation description and analysis - A practical Approach. West Sussex: John Wiley \& Sons Ltd.

Kim, D. \& Yu, K. B. 2009. A conceptual model of coastal dune ecology synthesizing spatial gradients of vegetation, soil, and geomorphology. Plant Ecol. 202:135-148.

Kimmins, J. P. 1987. Forest ecology. New York: MacMillan Publ.

Larcher, W. 2006. Ecofisiologia vegetal. São Carlos - SP: Rima.

Lemos, M.C.; Pellens, R. Lemos, L.C. 2001. Perfil e florística de dois trechos de mata litorânea no município de Maricá - RJ. Acta Bot. Bras. 15 (3):321-334.

Martins, F.R. 1989. Fitossociologia de florestas do Brasil: um histórico bibliográfico. Pesquisa 40: 103-164.

Matallana, G..; Wendt, T.; Araújo, D. S. S.; Scarano, F. R. 2005. High abundance of dioecious plants in a tropical coastal vegetation. Amer. Journ. of Bot. 92 (9):1513-1519;

McCune, B.; Mefford, M.J. 1999. PC-ORD. Multivariate Analysis of Ecological Data. Version 3.11 MjM Software Design. U.S.A, pp. 237.

Ministério de Minas e Energia. 2006. Mapa Geológico do Estado do Piauí. Brasília - DF: 1 mapa e 8 mapas aux., color. Escala: 1:1.000.000.

Mohr, E.C.J; Van Baren, F.A. 1959. Tropical soils. A critical study of soil genesis as related to climate, rock and vegetation. New York, Interscience Publishers.

Peel, M.C.; Finlayson, B.L.; McMahon, T.A. 2007. Undated world map of the Köppen-Geiser climate classification. Hydrol. Earth Syst. Sci. 11: 1633-1644.

Pereira, M. C. A.; Araújo, D. S. D. \& Pereira, O. J. 2001. Estrutura de uma comunidade arbustiva da restinga de Barra de Maricá - RJ. Revta. Brasil. Bot. 24 (3): 273-281, São Paulo.

Pires, L. A. 2001. Aspectos da ciclagem de nutrientes em uma formação de restinga na Illha do Mel, Paranaguá, PR. Dissertação (Mestrado em Ciências Biológicas). Instituto de Biociências, Universidade Estadual Paulista Júlio Mesquita Filho, Rio Claro - SP

Poulter, B.; Qian, S. S. \& Christensen, N. L. 2009. Determinants of coastal treeline in the role of abiotic and biotic interactions. Plant Ecol. 202:55-66.

Queiroz, L. P.; Conceição; A. A.; Giulietti, A. M. 2006. Capítulo 1: Nordeste semi-árido: caracterização geral e lista das fanerógamas. In: Giulietti, A. M.; Conceição, A.; Queiroz, L. P. (eds.) Diversidade e Caracterização das Fanerógamas do semi-árido brasileiro. Vol. 1. Recife: Instituto do Milênio do Semi-Árido: MCT. pp. 15-364.

Richards, T.W. 1996. The tropical rain forest. $2^{\text {nd }}$. Ed. Cambridge Univ. Press: London.

Rocha, J.C.; Rosa, A.H.; Cardoso, A.A. 2004. Introdução à Química Ambiental. Porto Alegre: Bookman,

Sá, C.F.C. 1992. A vegetação da Restinga de Ipitangas, Reserva Ecológica de Jacarepiá, Saquarema (RJ): Fisionomia e listagem de Angiospermas. Arq. J. Bot. RJ, 21:87-102. 
Sacramento, A. C. S.; Zickel, C. S.; Almeida JR. E. B. 2007. Aspectos florísticos da vegetação de restinga no litoral de Pernambuco. Rvta. Árvore, 31 (6): 1121-1130.

Scarano, F.R. 2000. Marginal plants: functional ecology at the Atlantic Forest periphery. In: Cavalcanti, T.B.; Walter, B.M.T. Tópicos atuais em Botânica. Embrapa/SBB: Brasília-DF. pp.176-182.

Scarano, F.R. 2002. Structure, Function and Floristic Relationships of Plant Communities in stressful Habitats to the Brazilian Atlantic Rainforest. Annals of Botany. 90:517-524.

Shepherd, G.J.1995. Fitopac 1.0. Manual do Usuário. Universidade Estadual de Campinas, Campinas.

Silva, J. G.; Oliveira, A. J. 1989. A vegetação de restinga do município de Maricá - RJ. Acta Bot. Bras., 3 (2): 253-272.

Silva, S. M. 1990. Composição florística e fitossociologia de um trecho de floresta de restinga na Ilha do Mel, município de Paranaguá, PR. Dissertação (Mestrado em Biologia Vegetal), Universidade Estadual de Campinas, Campinas - SP.

Silva, S. S. L.; Zickel, C. S., Cestaro, L. A. 2008. Flora vascular e perfil fisionômico de uma restinga no litoral sul de Pernambuco. Acta Bot. Bras. 22 (4): 1123-1135.

Silva, S. M.; Britez, R.M. 2005. A vegetação da planície costeira. In: Marques, M.C.M.; Britez, R.M. (orgs.). História Natural e Conservação da Ilha do Mel. Curitiba: Ed. UFPR. p. 49-84.

Sousa, M. J. N.; Rodrigues Neta, F. R. 1996. III - Litoral do Piauí: configuração e caracterização dos atributos geoambientais. In: CEPRO, Macrozoneamento Costeiro do Estado do Piauí: relatório geoambiental e sócio-econômico. Teresina: Fundação CEPRO. pp. 43-72.

SPSS Inc. 2000. SPSS 10,0 for Windows. Chicago: SPSS Inc. CD-ROM.

Sugiyama, M. 1998. Estudo de florestas da restinga da Ilha do Cardoso, Cananéia, São Paulo, Brasil. Boletim do Instituto de Botânica. 11:119-159.
Sutcliffe, J. F.; Baker, D. A. 1989. As plantas e os sais minerais.[tradução A. Lambert, V. M. Lotto]. - São Paulo: EPU. (Temas de Biologia; v.33)

Sztutmam, M.; Rodrigues, R. R. 2002. O mosaico vegetacional numa floresta contínua da planície litorânea, Parque Estadual da Campina do encantado, Pariquera-Açu, SP. Revta. Brasil. Bot., 25(2):161-176.

Taiz, L.; Zeiger, E. 2003. Plant physiology $3^{\text {rd }}$. ed. Sunderland: Sinauer Associates. 690pp.

Ter Braak C.J.F. 1986. Canonical correspondence analysis: a new eigenvector technique for multivariate direct gradient analysis, Ecology 67: 1167-1179.

Ter Braak C.J.F. 1987. The analysis of vegetation environment relationship by canonical correspondence analysis. Vegetatio 69: 69-77.

Ter Braak C.J.F. 1995. Ordination. In: Data analysis in community and landscape ecology (R.H.G. Jongman, C. J. F. Ter Braak \& O.F.R. van Tongeren, eds.). Cambrigde University Press, Cambrigde, p.91-173.

Trindade, A. 1991. Estudo florístico e fitossociológico do estrato arbustivo-arbóreo de um trecho de floresta arenícola costeira do Parque Estadual das Dunas, Natal (RN). Dissertação (Mestrado em Botânica). Programa de Pós-Graduação em Botânica, Universidade Federal Rural de Pernambuco, Recife.

Velloso, A. L.; Sampaio, E. V. S. B; Pareyn, F.G.C. (ed.) 2002. ECORREGIÕES Propostas para o bioma Caatinga. Recife: Associação Plantas do Nordeste; Instituto de Conservação Ambiental The Nature Conservancy do Brasil. 76p., il., Fig. Mapas.

Wijesinghe, D.K.; John, E.A.; Hutchings, M.J. 2005. Does pattern of soil resource heterogeneity determine plant community structure? An experimental investigation. Journal of Ecology. 93:99-112.

Zar, J.H. 1996. Biostatistical Analysis. New Jersey: Prentice-Hall. 